DOI: 10.11606/issn.2238-3867.v17i2p436-453

sala preta

ppgac

Dossiê Branco: o cheiro do lírio e do formol

\title{
NOTAS SOBRE BRANCO
}

\author{
NOTES ABOUT BRANCO
}

José Fernando Peixoto de Azevedo

José Fernando Peixoto de Azevedo

Professor da Escola de Arte Dramática da USP.

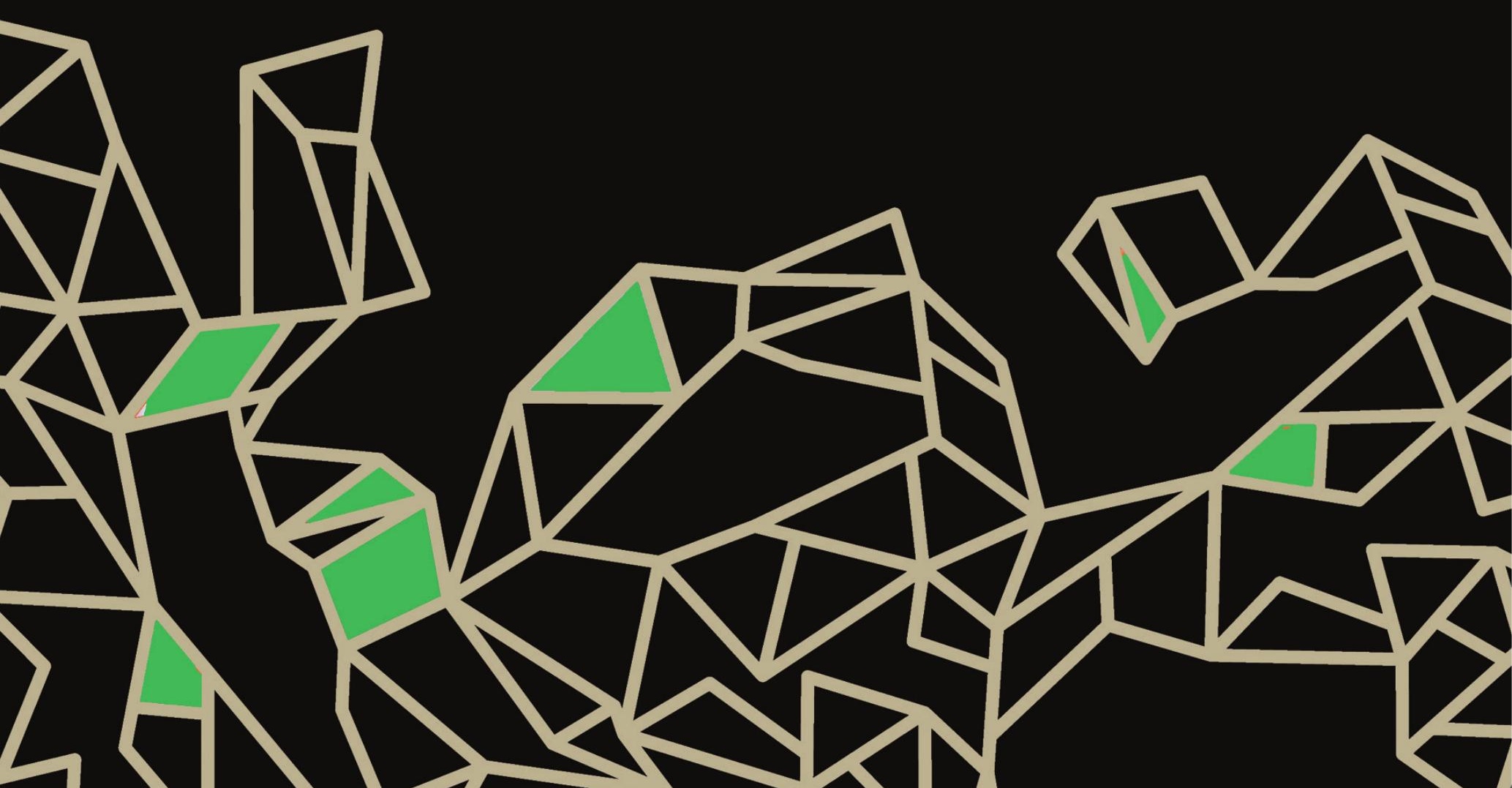




\section{Resumo}

Branco configura-se como um dispositivo de captura a determinar aspectos de sua recepção. Essa dinâmica opera por desvios e exige uma reflexão sobre as relações entre tema e forma. Trata-se de saber como o racismo informa esse material.

Palavras-chave: Dispositivo, Forma, Racismo.

\section{Abstract}

Branco is configured as a capture device to determine aspects of its reception. This dynamic operates by deviations, and requires a reflection on the relations between theme and form. It is about how racism informs this material.

Keywords: Device, Form, Racism.

Ouvir é um fenômeno fisiológico; escutar é um ato psicológico. Pode-se descrever as condições físicas da audição (seus mecanismos), recorrendo-se à acústica e à fisiologia da audição; a escuta, porém, só se pode definir por seu objeto, ou, se preferirmos, sua intenção.

Roland Barthes ${ }^{1}$

Escrever sob condições nas quais a consciência do caráter associal da escritura não pode mais ser suplantada. O talento já é um privilégio. Privilégios devem ser pagos: a contribuição pessoal de sua desapropriação pertence aos critérios do talento. Com o mercado livre cai a ilusão da autonomia da arte, um pressuposto do Modernismo.

Heiner Müller

1.

Branco: o cheiro do lírio e do formol, peça escrita por Alexandre Dal Farra e dirigida por ele e Janaína Leite, configura-se como um dispositivo:

1 BARTHES, R. A escuta. In: O óbvio e o obtuso: ensaios críticos III. Tradução Léa Novaes. Rio de Janeiro: Nova Fronteira, 2014. p. 217.

2 MÜLLER, H. O espanto como a primeira aparição do novo: para uma discussão sobre a pós-modernidade em Nova York. In: KOUDELA, I. (Org.). Heiner Müller: o espanto no teatro. São Paulo: Perspectiva, 2003. p. 45. 
a cena arma-se como um dispositivo que a tudo quer abarcar. Em sua oscilação, a peça exclui tudo aquilo que não conhece e expele tudo aquilo que supostamente conhece demais. Operando assim, a tudo incorpora na medida mesma em que faz com que todas as relações se desincorporem. Ao fim, nada lhe é exterior. Aquilo que é enunciado como ausência na peça não escapa a esse movimento.

\section{2.}

Não será por acaso, talvez, uma certa recorrência na recepção da peça: a contraposição performativa entre uma experiência afirmativa de si e o vazio sem preenchimento de uma experiência negada. Como ocorre com a figura do autor na peça (essa espécie de derivação performativa que se quer uma voz da qual todas as outras em cena são eco), tem sido comum que, para falar da peça, aquele que fala fale também de si, ou de sua condição.

\section{3.}

Mas Branco, dizem, é uma peça sobre racismo. E sim, a figura do autor de tempos em tempos volta à cena para nos lembrar disso. Desde o início, esse era o plano. O título original do projeto armava-se como cifra do problema: Ele escreveu uma peça sobre negros. Como se vê, o foco sempre esteve nele. Mas ocorre que ao assistir à peça algo se compreende. Branco: o cheiro do lírio e do formol não é uma peça sobre racismo. (Se se trata ou não de uma peça racista, a conclusão deveria resultar de uma análise cujos critérios precisam ser explicitados.) A cena, antes, deixa emergir a imagem de um modo de vida no interior do qual o racismo é um momento, uma vez que esse modo de vida é ainda regido por um inconsciente escravocrata. Em cena, uma vida capturada por dispositivos de esvaziamento e anulação. Uma vida que, vazia e anulada, todavia se move e produz seus efeitos. O traço regressivo não é pequeno; há tudo ali, inclusive sacrifício.

Se a ambiguidade define o gesto dessa dramaturgia, em mais de um sentido Branco corre o risco de realizar aquilo que denuncia. Como a peça 
parece não recuar diante dos riscos, um de seus ganhos é permitir ver emergir nessa cena esse modo de vida que ainda podemos nomear fascista.

4.

O regime da falta é a moldura que enquadra a peça, desde a primeira cena. Dissimulada numa cena doméstica, a família disfuncional que a habita desenha o movimento parado de uma ciranda cancelada. O pai sem qualidades; o filho sem mãe, que já não reconhece no pai qualquer exemplaridade; a tia do menino, irmã do pai, que não substitui a mãe e intui o sentido do bloqueio:

Deixa pra lá então. A gente está velho. Não tem mais o que fazer. Os bons tempos já passaram. E agora o que sobrou para nós é o quê? Nada. Ficar olhando para trás e sentindo pena de nós mesmos. Eu não quero fazer isso. (DAL FARRA, 2017a, p. 6) ${ }^{3}$

Há, então, essa experiência do tempo como adiamento e cancelamento, essa vida vista pelo retrovisor que parece ser toda a vida, ou o único modo de vivê-la. $O$ adiamento não se confunde com espera. $O$ que produz o sem sentido aqui já não é uma experiência de pura expectativa, mas a reiterada anulação de qualquer expectativa, quando o horizonte pode se confundir com o farol visto por um motorista dentro de seu carro (o objeto de projeção do pai, em sua imobilidade mórbida), que no entanto o ultrapassará sem que tal ultrapassamento signifique qualquer coisa que não apenas uma reiteração da norma. Aqui, a paisagem é o depósito daquilo que há muito foi descartado, e o que resta do tempo torna tudo o mesmo:

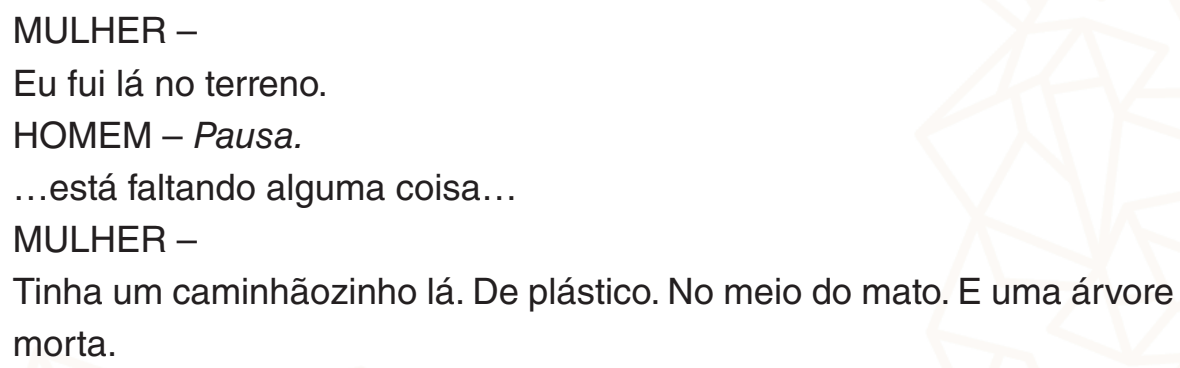

3 Todas as citações da peça se referem a essa versão usada na encenação. 


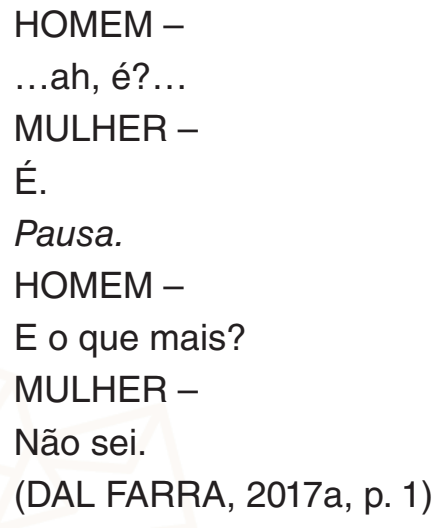

Na figura do pai, figura fraca e impotente diante das demandas, inclusive do filho, a falta aparece como cifra de uma vida vazia e a exigência de preenchimento sem qualquer satisfação. A monotonia não dissimula a reincidência do mesmo: o dinheiro, o carro ou a exigência de satisfação imediata que, no filho, ganha ares de perversão:

Pausa.

MENINO -

Pai, me dá um dinheiro.

HOMEM -

Não tenho mais.

MULHER -

Tó. Eu te dou.

Ela dá uma nota a ele.

MENINO -

Mas é muito pouco.

HOMEM -

Pra que você quer tanto dinheiro?

MENINO -

Pra comprar uma coisa.

HOMEM -

Que coisa?

MULHER -

Você está muito parecido com o seu avô.

HOMEM -

Vai dormir agora.

MENINO -

Não, mas ainda está cedo. Eu não consigo dormir essa hora. Eu deito na cama e fico parado, e não durmo.

MULHER -

Deixa ele ver televisão. 


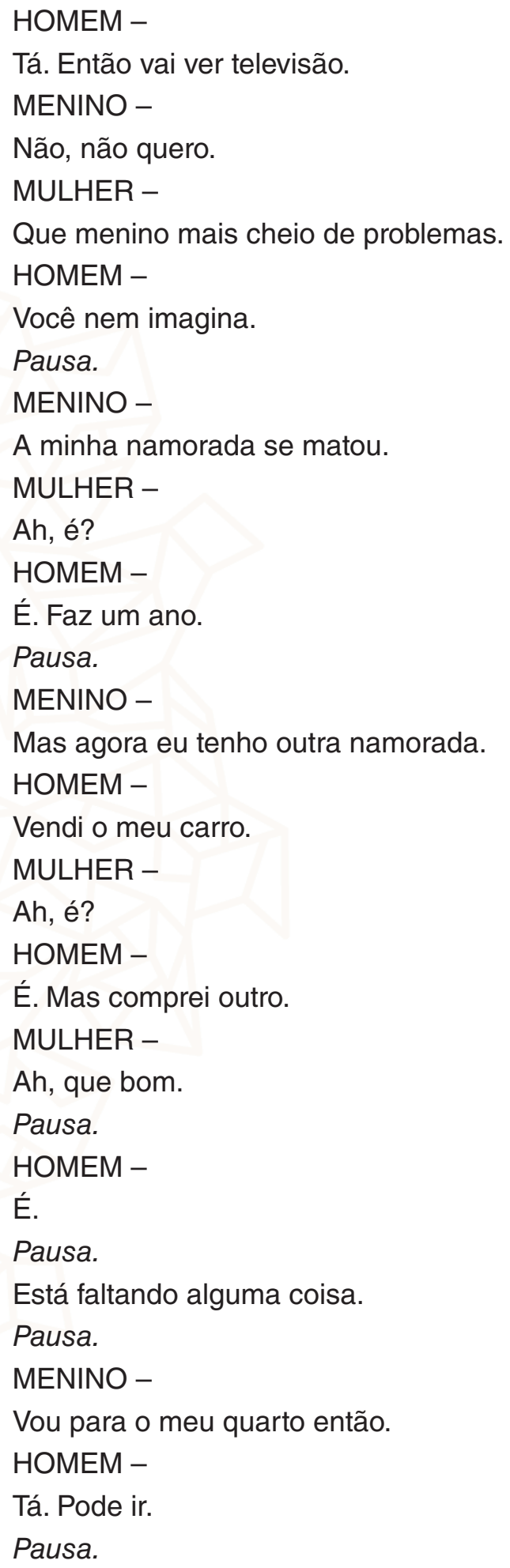

A impossibilidade do aprendizado, em Branco, faz lembrar algo daquela mutação antropológica que Pier Paolo Pasolini flagrava já no final dos anos 1960. As novas formas do fascismo - este, em mutação constante-conformam 
um amálgama de sem sentido, conformismo, violência, individualismo, derrisão e cinismo, manifestados numa espécie de inexpressividade programada:

MENINO -

Posso voltar para o quarto?

HOMEM -

Não.

MULHER -

Deixa ele.

HOMEM -

Ele precisa aprender um pouco também.

Pausa. A mulher limpa a boca com um pano.

MULHER -

Mas pra quê?

HOMEM -

Não sei.

Pausa.

MENINO -

Eu sei.

MULHER -

Ah, é?

MENINO -

Eu estou crescendo. Me tornando um homem. Eu olho para isso e não sinto nada. Eu vejo o que me espera do lado de fora da minha casca. Eu tenho essa casca. Essa casquinha. Que eu preciso romper. É uma casca fina e transparente. Sabe?

Pausa.

HOMEM - Para a mulher.

Eu estou precisando de dinheiro. Se você não está precisando de dinheiro, eu estou precisando de dinheiro.

MULHER -

Bom, eu não estou.

Pausa.

MENINO -

Posso sair um pouco?

MULHER -

Não, é melhor não. O seu pai está certo. Você precisa escutar ele. O seu pai. Esse cara aí. Olha pra ele.

Pausa. O menino olha. Começa a escorrer uma baba preta da boca do homem. Pausa.

HOMEM -

...você não acha também? Eu estou sentindo falta de alguma coisa!...

Pausa. 
MENINO -

Eu já sei dirigir, sabia, tia?

MULHER -

Olha aí. Que bom.

(DAL FARRA, 2017a, p. 8-9)

O pai é ora esse modelo vazio, cuja exemplaridade expirou - o que não impede que o filho a repita -, ora o passado que não passa, o pai doente que morre no hospital, e que no entanto não morre, porque nunca esteve no hospital - trânsito que excede o jogo de palavras ao revelar, mais que uma dissimulação, a consciência acerca de um regime de oscilações e permanências, sem que a metáfora possa agora cicatrizar as feridas dessa ordem que a todos abarca, sem que se possa impunemente nomeá-la:

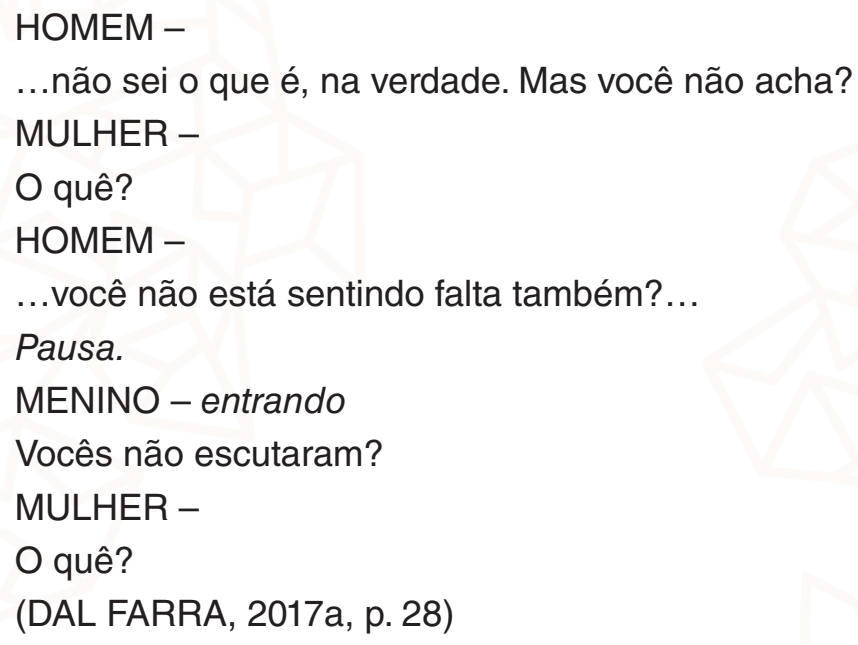

Ainda não por acaso, na explicitação do ensaio como forma, em uma das retomadas de materiais no jogo da peça, comentando a sua reescritura, um outro sentido da falta aparece:

Escrevi uma peça nova, sentindo o tempo todo que dessa vez eu estava me colocando de forma responsável. Essa nova peça falava sobre uma jornada de aprendizagem de um sobrinho com o seu tio, que o levava para conhecer o sítio que tinha sido do seu avô, e lá acontecia uma série de coisas, até que o tio se embriagava e o sobrinho tinha que voltar guiando para casa. Nesse retorno, ele atropelava uma mulher negra. Eles acabavam levando a mulher, desacordada, para a casa do sítio, e depois descobriam que ela fazia parte de um tipo de movimento que, ao 
dar falta dela, ia à sua procura, encontrava o tio e o sobrinho, e os matava. (DAL FARRA, 2017a, p. 25)

Como numa daquelas peças naturalistas do século XIX, o mais importante é a ação, e a ação está fora da cena. Aqui, a figura da mulher negra sequestrada será resgatada, e esse resgate não ocorre sem vingança. Nesse caso, o movimento da falta não exige o preenchimento por outra coisa, mas demanda aquilo que está ausente na sua qualidade mesma, e isso não se dá sem que a violência que originou a falta tenha como resposta uma violência complementar. Esse "tipo de movimento que, ao dar falta dela, ia à sua procura" reforça a ideia (tão insistente na peça) de que ali não é o seu lugar: ela deverá ser resgatada desta cena ainda uma vez.

Esse movimento de resgate, que entretanto não se efetiva em cena, deixa ver uma espécie de intuição. O que a cena de Branco parece evidenciar, e nesse sentido seu movimento revela um movimento maior, é que, quando esse negro ocupa a cena, trata-se já de uma outra cena. Por isso, a cena reage, fazendo dessa presença uma demanda, ao mesmo tempo que a devolve ao regime de insatisfação e impossibilidade: não há satisfação da demanda sem transformação da cena e, nesse caso, essa transformação se confunde com a sua supressão.

\section{5.}

Há no teatro de Dal Farra uma espécie de aprofundamento, em chave performativa, daquele programa que marcou o chamado "teatro brasileiro moderno", como um empenho de exposição da vida como ela é:

Nesse sentido, não me interessa tanto um teatro que mostre o que deveríamos ser, nem que mostre como o mundo deveria ser, mas sim um teatro que possibilite que olhemos justamente para o que o mundo não deveria ser (mas ainda é). E para o que nós não deveríamos ser (mas ainda somos). Todos nós carregamos, queiramos ou não, o gene da estrutura violenta, opressora, desigual que nos forma. Ninguém está livre das amarras do mundo onde nasceu. E o nosso mundo é péssimo. Fazer um teatro que simplesmente se limpe disso tudo para entrar em cena 
como se estivéssemos prontos para adentrar o paraíso simplesmente não me interessa.

O lugar do teatro tem servido, nesse sentido, para que se abra espaço, justamente para que tudo aquilo que nós normalmente escondemos (e, ao esconder, enrijecemos) possa se mover. Para que tudo o que é tabu possa deixar de sê-lo - porque o movimento enfraquece o mal; o espaço enfraquece o mal, e o simples esquecimento, a repressão, a tentativa de exclusão só o fortalece. (DAL FARRA, 2017b)

O programa está todo aí, nessa reiteração daquilo que ainda é, numa resistência a todo dever ser, mesmo quando isso implica o reconhecimento daquilo que não deve ser. No caso de Branco, esse princípio tem efeito estruturante. Como um viveiro de horrores, a cena converte-se em um campo de exposição. A ideia do mal, não sendo exata, faz supor uma crítica ao estágio atual da sociedade e sua razão operatória. Todavia, a metáfora do movimento confunde, já que não é possível dissociar simplesmente modernidade e movimento. $O$ capitalismo, nos últimos cem anos, mostrou que: não, o movimento não enfraquece o mal; e todo espaço pode ser por ele colonizado. Brecht talvez tivesse isso em mente, quando elaborava seus procedimentos de interrupção, como aliás faz ver o comentário de Walter Benjamin.

Trata-se, já se vê, de flagrar o movimento destrutivo que toma conta da vida em seus mais diversos aspectos, ao mesmo tempo em que não se hesita em depor sobre a cena um gesto destrutivo, ele mesmo resultado do esforço de ir ao cerne das situações, numa espécie de autópsia de um corpo imaginado.

O autor justifica seu gesto citando Walter Benjamin e seu texto sobre o caráter destrutivo. Em Benjamin, porém, é das ruínas que algo emerge, porque é ainda em direção a um horizonte que se lançam as apostas, mesmo que a contrapelo dos fatos. Nesse caso, a destruição é um gesto, não um projeto. Aliás, a destruição como projeto sempre esteve em outro campo, e bastaria lembrar das formulações de Heidegger - mas isso, claro, é outro assunto. 
6.

Ao seu modo, Branco é uma peça de aprendizagem sobre a dificuldade de aprender. Seu pressuposto é o de que o branco que a nomeia é também um coro. Com efeito, a cena não deixa de acenar para a plateia. Não sendo imediata a adesão a seus pontos de vista, seu trabalho sugere uma demorada aderência à superfície de seus impasses. A figura do autor, em cena, emerge como um envergonhado corifeu, apelando à plateia, como se de costas para a cena - imagem que poderia lembrar ainda uma vez Benjamin, mas agora a figura de seu Anjo, não fosse a resistência da cena em relação à História (ou seria já a resistência dos materiais?).

Em sua forma, Branco é uma peça-ensaio, permitindo-se deslizar pelos materiais. Um ensaio sobre a cegueira como prática de relação com o outro. Mas se o outro é o negro, mais do que ausente, ele é aquele a quem falta, aquele que insiste em dizer: eu não estou aí. 0 que quer dizer que essa falta não o define, ela está para o outro, sempre. Esse que diz "não estou aí" está em outra parte. Já o branco da peça não é aquele que tem dificuldade de estar nesse outro lugar, mas aquele que precisa fazer de todo lugar o seu lugar.

Na economia de Branco o negro é matéria de ensaio, tema cercado e comentado, ao custo de exemplos-clichês do racismo segundo uma visão reiterada e reiterativa.

É nesse sentido que a peça não é sobre o racismo, mas uma peça que faz ver um modo de vida que, sendo também fundamentalmente racista, se revela incapaz de compreender aquilo que não seja ele. Ocupado demais em compreender o que ele é, desconhece o fato de que boa parte do que se tornou é precisamente aquilo que o outro sabe dele, e ele ignora.

Já ao negro, treinado na invisibilidade, não é permitido não ver: a todo tempo vê no outro uma reação, uma negação; ali uma interdição, aqui uma desqualificação. Todo o tempo ao negro é exigido reconhecer "o seu lugar," e isso é principalmente o olhar do outro que não cessa de indicar. 
A certa altura, comenta-se em cena a conversa com artistas que participaram em momentos do processo de produção da peça como comentadores do material (eu mesmo, este que escreve esse esboço de ensaio, fui um deles). A um desses "provocadores" foi enviado um e-mail, falando da dificuldade em responder às críticas:

$\mathrm{Na}$ época em que enviamos esse e-mail, chegamos a pensar inclusive em não fazer mais nada. Em desistir. Deixar tudo isso de lado. Mas deixar tudo de lado seria o nosso maior privilégio. Poder simplesmente mudar de assunto, não falar mais sobre isso, voltar para as nossas outras peças, que tratam sobre qualquer outra coisa. Isso sim era a marca maior do nosso privilégio. Por outro lado, nós também não fomos capazes de fazer a peça junto com os parceiros negros, as parceiras negras, que nós tínhamos proposto no e-mail. Esse caminho também simplesmente não foi trilhado - e mesmo o provocador não o viu como uma possibilidade real. Porque talvez ele também fosse no fundo uma tentativa de escamotear um problema maior. Talvez a vontade de fazer uma peça sobre racismo junto com artistas negros tenha sido mesmo uma vontade de tentar transpor a fórceps uma fissura social muito maior do que todo o nosso voluntarismo teria sido capaz de sequer perceber. Será que estamos prontos, enquanto sociedade, para fazer algo juntos? Essa pergunta não é retórica. Mas o próprio fosso que sempre se abre, em qualquer tipo de discussão sobre tudo o que se liga a racismo, entre o que os brancos em geral escrevem e dizem (nós inclusive), e o nível de elaboração dos negros sobre os mesmos assuntos, nos mostra por si só que nós, brancos, temos muito para caminhar antes de que talvez possamos nos encontrar em algum lugar. Querer transpor esse fosso antes de que nós, brancos, aceitemos plenamente a sua existência e o percebamos como um problema nosso, nos pareceu inviável. (DAL FARRA, 2017a, p. 23-24)

Como responder a essa pergunta: "Será que estamos prontos, enquanto sociedade, para fazer algo juntos?"

A peça responde com um adiamento. Como num filme de suspense, trata-se de adiar a solução. Nesse caso, no entanto, não há suspense, pois se trata de um adiamento sem tensão. Em cena, tudo é esgarçamento e, desde sempre, se há alguma angústia, ela se dá pelo fato de que todos sabemos, dentro e fora da cena, que nada acontecerá. Em seu movimento de captura, a cena insiste em fazer do fora o seu avesso: 
Se isso aqui fosse um filme de terror, este seria o momento exato em que o protagonista atende o telefone, e alguém do outro lado descreve exatamente as roupas que ele está usando, assim como os todos seus movimentos, inclusive quando ele olha para trás, ou para os lados. Neste momento ele teria acabado de desligar o telefone e estaria olhando pela janela, para o quintal escuro, tentando flagrar algum movimento do lado de fora, quando veria de relance o vulto do invasor, ali, refletido no mesmo vidro que ela. Esse momento seria exatamente a hora em que o protagonista constata, em um milésimo de segundo, que o invasor não estava do lado de fora, onde ele o procurava, mas, muito mais perto: ali, do seu lado, dentro da sua própria casa. Eu estava com medo de mim mesmo. (DAL FARRA, 2017a, p. 36)

Na peça, a voz que vem de fora - desse colaborador que é nomeado um provocador - sugere um momento de escuta. Escuta e fala definem um pouco do que somos, já que uma não vai sem a outra. Toda escuta é política.

8.

E aqui, o programa do autor se revela em toda a sua ambiguidade. Se ao autor Alexandre Dal Farra não

interessa tanto um teatro que mostre o que deveríamos ser, nem que mostre como o mundo deveria ser, mas sim um teatro que possibilite que olhemos justamente para o que o mundo não deveria ser (mas ainda é), (DAL FARRA, 2017b)

a figura do autor na cena adia o teatro, precisamente quando percebe que

talvez a vontade de fazer uma peça sobre racismo junto com artistas negros tenha sido mesmo uma vontade de tentar transpor a fórceps uma fissura social muito maior do que todo o nosso voluntarismo teria sido capaz de sequer perceber. (DAL FARRA, 2017a, p. 24)

Mas não é assim desde os gregos? O teatro como tentativa de encontrar o outro, de ver o outro sem que sua presença paralise aquele que vê. $O$ teatro, como aquele lugar de onde se vê, é precisamente esse lugar "protegido" pelo jogo da cena, que nada mais é que o trabalho poético de fazer ver sem 
paralisar frente aos impasses medusantes da vida na cidade. Desde sempre, no teatro, o outro é portador de notícias difíceis que chegam de fora, sobre os que já estão ali ("nós mesmos").

9.

A escravidão produziu no Brasil uma espécie de trânsito que esfumaça os limites entre vida pública e vida privada, produzindo uma envenenada intimidade, tão intensa que opera por uma espécie de confusão: o negro é tão próximo, tão presente, que já não é visto, uma vez que o outro não aparece aos olhos sem que alguma distância se produza. A presença do negro sempre foi vivida como um excesso. Estando em toda parte, o negro contudo não tinha lugar algum. Eis a lógica da exceção brasileira: o negro, não estando ausente, é aquele a quem falta, e essa falta é uma condição. Ausência como falta, nesse caso, implica a demanda de presença, ou a sua recusa. Esse é o movimento pendular que ainda toma conta da nossa vida social.

10.

Como nos faz lembrar o performer negro estadunidense Willian Pope. L: PESSOAS BRANCAS SÃO O QUE LHES FALTA4 ${ }^{4}$. Essa problematização da falta como constituinte e constituição faz pensar muito sobre o teatro no Brasil, principalmente num momento em que, face à emergência de uma cena que se reclama como um teatro negro, o que precisamente aparece no centro do debate é o significado da presença negra na cena, agora não mais apenas como tema.

A presença do corpo negro na cena torna incontornável seu poder de demonstração, já que um negro não representa um negro, um negro é um negro - até que ele próprio diga outra coisa.

A questão leva longe o debate, considerando o modo como, no Brasil, o teatro se constituiu a partir dessa supressão. Basta lembrar que a ideologia do teatro nacional e da nação foram forjadas sem que pesasse sobre seu enunciado o fato de que a grande maioria da nação estava fora - da nação e

4 Conferir a análise que André Lepecki (2017) faz do trabalho de Pope L. 
do teatro. "Formação supressiva", como já explicou José Antônio Pasta Junior (2011).

Se quando vemos um negro em cena é ainda uma falta o que vemos, um teatro negro não é apenas o lugar e o momento de produção de uma presença, como quem preenche a falta, o buraco, mas talvez seja já uma crítica imanente: uma alteração temporal que, ao permitir ver duas vezes uma mesma cena, verifica que aquele corpo estava ali todo o tempo, e que sua invisibilização pressupõe um olhar que a reitere. Ou seja, não basta alterar os corpos da cena, é preciso recorrer a outros corpos que veem. Isso porque presença é também estar diante daquilo que é. Nesse caso, é gritante a exigência de mão dupla. Que diferença há entre o espectador e um policial? Já o corpo nós sabemos: tem sido visto como o preto revólver, ou o alvo preto.

O corpo de um ator negro é tema, é testemunho, é forma, é palco, é cena. Perguntarão: mas não é assim com qualquer corpo? Talvez. A diferença é que um corpo branco, em cena de teatro, se mistura com ela. Um corpo negro, em cena, também a de teatro, impõe a pergunta: que cena é esta? E se esse corpo negro se recusar a agir, a fazer coisas, então agravamos a situação. É ainda de uma falta que fala o branco, quando o branco fala de si.

A escravidão foi o corpo real da modernidade, sua carne, sua energia, uma tecnologia. Sua herança define, certamente, muito de nossa atualidade, uma efetiva dialética da colonização.

11.

Na peça, o vômito em sua branquidão dá cor a uma interioridade que se excede e vai a tudo tomando. Branquitude. Por isso esse vômito pode tornar-se preto a qualquer momento, mas por apropriação.

Essa exteriorização não se confunde com a exterioridade. Nesse fora onde tudo é violência e espoliação da vida - o "preto fica".

$\mathrm{Na}$ economia da cena, é sempre de dentro que se fala.

Excluir e expelir. Ao seu modo, já que nada lhe permanece totalmente exterior, em Branco, se o negro fala, ele é imediatamente capturado (a voz over). Machado de Assis, em seus romances, parece ter cifrado algo disso. 
Ali, a escravidão não apenas calava o negro, como o reduzia à sombra. Mas era precisamente essa condição e o processo de sua fabricação expostos, na forma literária, o que Ihe garantia a imagem completa. Já no teatro da vida como ela é de Nelson Rodrigues, o negro apareceu como algo que deveria desaparecer a cada emergência sua na cena - lembremos os assassinatos dos bebês pela mãe em $O$ anjo negro. A peça de Alexandre Dal Farra oscila entre a sombra e a supressão: na ameaça de emergência da presença: ou ela acusa, e com isso torna-se o fundo falso que mantém a cena sobre o porão da História, ou ela é impossível e nunca se efetiva, como se ameaçasse a própria cena - neste caso, a ser engolida pelo porão que a sustenta.

12.

Em Branco não há exatamente uma dialética entre um dentro e um fora; a passagem de um para o outro se dá sempre de maneira supressiva. O que está fora tem força de invasão, como as batidas na porta que aos poucos tomam conta da cena, de maneira ameaçadora.

Em outros momentos, a cena posiciona os atores em relação a uma câmera ao lado do palco, diante de uma mesa: ali, essa cena repõe, sob a luz baixa, a sua própria fantasmagoria: há algo de uma imagem de si a que tudo deveria corresponder, e que a tudo impõe a sua lógica, esta vivida como inescapável. Aqui, tudo se passa como se o depoimento fosse um elementochave da cena; mas o esforço por embaralhar o que seria um fato e o que seria seu desmentido, na peça, é mais forte do que a oposição entre documento e ficção. Aquilo que é e não é ao mesmo tempo, aquilo que aconteceu e não aconteceu ao mesmo tempo, tudo isso cria um plano de desintegração constante.

Ao fim, os corpos tomados por uma espécie de gosma branca, como o cadáver que deveria estar em cena, cumprem o seu destino, em estágio de decomposição. A peça perderia bastante de sua eficácia se não operasse ainda uma vez essa oscilação: na sua frontalidade mórbida, os atores atuam como quem vela algo e, não obstante, a cena se impõe como corpo a ser velado. Branco pode também ser um nome para essa mistura que resulta dos cheiros do lírio e do formol. A desintegração desses corpos expressa a 
desintegração de relações não porque estão no fim: a desintegração é a sua forma sem fim.

13.

Em 12 de outubro de 2017 estreou no Kammerspiele de Munique a peça Mittelreich, sob direção de Anta Helena Recke. Trata-se da apropriação - assim se definia - de uma encenação anterior, na qual Anta fora assistente, então dirigida por Anna-Sophie Mahler. Em cena, todos os detalhes da encenação anterior no seu cuidado para reproduzir os impasses de uma vida burguesa, enriquecida e marcada pelo período imediatamente após a Segunda Guerra Mundial, com vestígios dos compromissos de uma subjetividade ainda atravessada pelo horror e sua dissimulação na vida cotidiana herdados da cooptação nazista. Quase tudo como na encenação anterior, a não ser pelo fato de agora estarem em cena atores e músicos todos negros.

O sentido político dessa apropriação não escapou ao público, com sua reação entusiasmada, e nem à crítica. Mas chamou atenção, em particular, um aspecto da recepção por parte da crítica conservadora. Dizia respeito ao que se identificava ali como sendo uma suposta "falta" de "qualidade" do trabalho de alguns atores negros em cena. Mas então, o ponto: onde estão os atores negros alemães em cena? Se estão ausentes, não será natural que, postos em cena, as marcas dessa ausência se evidenciem? Mais uma vez, o negro ali aparecia como falta, como portador de uma falta (em relação a uma certa "qualidade do teatro alemão"). Mas vendo o espetáculo com olhos para vê-lo: se o outro é aquele que não é (branco, europeu etc.), então o outro não é?

$\mathrm{O}$ que isso tem a ver com Branco?

Em parte, Anta Recke, uma diretora negra alemã, faz a pergunta teatral que Alexandre Dal Farra, um autor e diretor branco brasileiro evitou.

A cena retomada de uma das versões, em que um ator e um diretor lutam pelo sentido das palavras revela o modo como, em Branco, se o teatro não é só o que vemos, ele, todavia, está longe de ser aquilo que imaginamos. Interditada a possibilidade de imaginar outra coisa, ao fim das contas já é cena a insistência em sua impossibilidade - que tantas vezes corre o risco de 
se confundir com um "tanto faz" - e o delírio é apenas a sua forma rebaixada. Para retomar a imagem de Benjamin, aqui, a cena não é aquele ponto alto da onda em seu momento de suspensão, mas o cancelamento mesmo da onda, ali, no momento anterior à sua formação, quando a água é devolvida à praia, sempre ainda uma vez.

Em uma das versões, era da ordem do sacrifício a demanda de desbloqueio - uma cena citada, entretanto em vídeo, como uma imagem daquilo que se imaginou e se cancelou antes mesmo de tornar-se cena. Mas não se ensaia o terror. Na história, um horror não é o ensaio de outro horror, mas apenas horror.

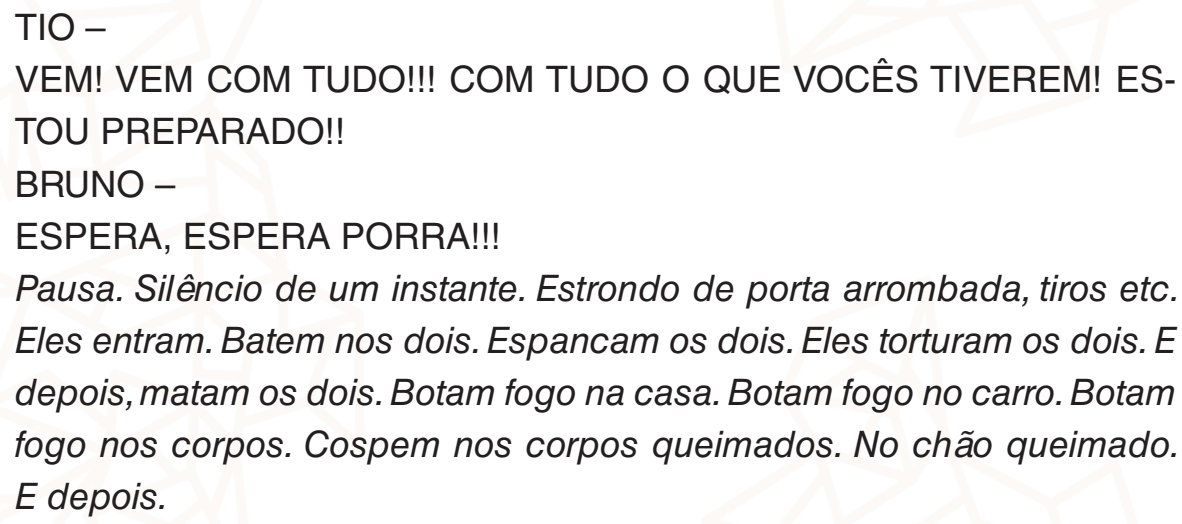
Eles entram. Batem nos dois. Espancam os dois. Eles torturam os dois. $E$ depois, matam os dois. Botam fogo na casa. Botam fogo no carro. Botam fogo nos corpos. Cospem nos corpos queimados. No chão queimado. E depois.

(DAL FARRA, 2017a, p. 27)

\section{Referências bibliográficas}

DAL FARRA, A. Branco: o cheiro do lírio e do formol. São Paulo 2017a. Mimeografado.

Por um teatro que coloque o mal em cena. Revista Cult, São Paulo, 15 maio 2017b. Disponível em: <https://goo.gl/EJBjX3>. Acesso em: 17 nov. 2017.

LEPECKI, A. Exaurir a dança: performance e a política do movimento. Tradução Pablo Assumpção Barros Costa. São Paulo: Annablume, 2017.

PASTA JR., J. A. Formação supressiva: constantes estruturais do romance brasileiro. Tese de livre docência - Faculdade de Filosofia, Letras e Ciências Humanas, Universidade de São Paulo, São Paulo, 2011. 